44, 437」,「ジ+ワ座カポック油, 同上, 523」「スマトラ座バーム 油, 同上，1011」及び「佛印产米㻖油，同上，昭和 $18 ， 46 ， 15$ 」 反就ての研究を夫々本研究第 1 - 5 疑々する。

䊏りに臨み, 本試料油の乾燥試羷に御捘助下さつた東京都工業獎 尉館化學部技師岩井信次氏几厚く謝意を表する。

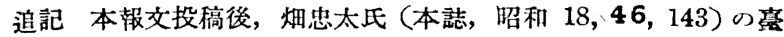

瀿，海南岛及び廣東党くくい油に就ての報告に接した。

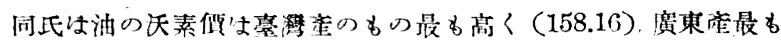

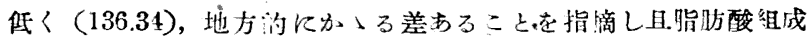
を異にするも，夫々固體酸の含量少くリノー儿酸を主成分とするこ とを認めた。また動物试铪の結果, 食用油としてる使用し得るてと を明かにした（昭和 18 年 3 月 30 日）。

\title{
(280) 高壓還元によるソルビット類の合成に就て
}

山本偆 一

\section{I. 緒‧言}

現在ソルビット，マンニット，キシリット等多價アルコールをし て多岐に涉る工㧛用途が進展して來をのであるか（山本：本誌，昭 和 17, 45, 933; A. Sch: Chem. Ztg., 1938, 62, 196), 所謂上記 糖アルコール類の合成法々しては蔽菊糖, 果裾, 木糖の如き單榶類 或は蕉糖, 麥芽糖の如き二䌅類, 乃至は澱粉, デキストリンの如き 多糖類より合成し得るものであり, 例一ば單榶類飞就てはイうナト

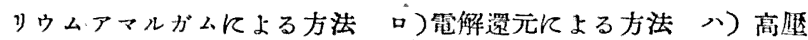
鿷元に上る方法等が舉げられるが工業的には勿論後二者に上るの である(H. Jermain, Creighton:Chem. Ind., 1940, 59, 557)。 外國に於ては主として電解法を行ってるる樣であるが, 著者等は高

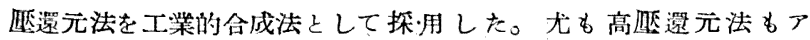
ルコール溶液中にて銅クロム系觸媒に上る場合と水溶液に於て二ッ ケル珪藻土によるものがあるが賞然工業讪には後者が有利であり 操作が簡單である。本方法に就ては既に本邦に於て古河清氏(理研

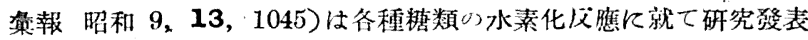
があり, 沿周知の H. Adkins 等の報文もある。又 5 價アルコー

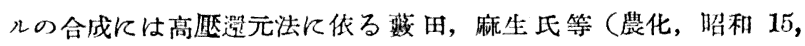
16, 1077)のキシリットの合成關する發表がある。

著者は工業规模にて各種溉粉或は葜萄榶よりヴィタミン $\mathrm{C}$ 合成 原料としてッルビットの合成を行つてみるが, 特來け大量资源とし て南方資源たるサゴ排子, タピオ力或は蔗糖等の瑖粉或は廣く炭水

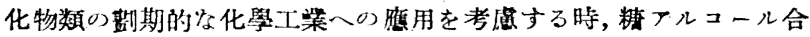
成の基礎的條件の明確を必要とする目的を以て反應溫度，水素远

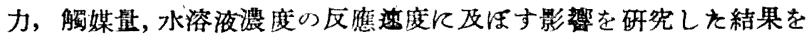

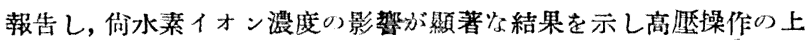

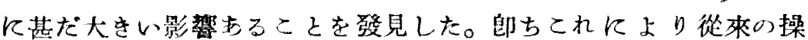
作條作より遙に低溫低厘にて處理し得る事が明かとなつた。又例 一壮ソルビットの合成に關しても敢て莆苜糖を必要とする事なく極

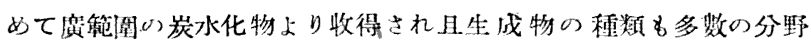
に涉り有機化學工業の一翼として溉粉乃至は炭水化物の化學工業

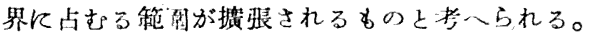

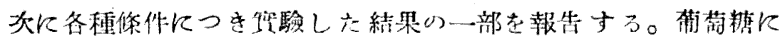
關する條件は水素イオン濃废の場命のみを記し主として蕉潇に關

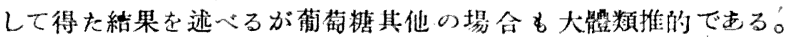

ただ水素イオン濃度の場合は蔗糖に於ては直揬的には效果は現れ ない。

\section{II. 赛 驗 の 部}

實驗に使用したオートクレーヴは西式振蕰式內容 $630 \mathrm{cc}$ のも のである，而して觸媒は（炭酸ニっヶル):(珪藻土)の $2: 3$ のも のより調製せるニッケル觸媒を使用した。

第 1 表・反應溫度に依る還元速度の影響 試料 150 : 水素初唯 $150 \mathrm{~atm}$; 懐度 $60 \%$ 溶液; ニッケル珪欂士 $5 \mathrm{~g}$

\begin{tabular}{|c|c|c|c|c|}
\hline 贯驗記號 & 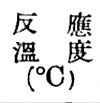 & $\begin{array}{c}\text { 区 㤫 } \\
\text { 時 間 } \\
\text { (分) }\end{array}$ & $\begin{array}{l}\text { 水素吸 } \\
\text { 收量 } \\
\text { (atm) }\end{array}$ & $\begin{array}{l}\text { 殘留薦 } \\
\text { 榶分 } \\
(\%)\end{array}$ \\
\hline No. $\mathrm{T}-1$ & 130 & 150 & 13 & 89.55 \\
\hline$" \mathrm{~T}-2$ & 140 & 140 & 37 & 62.78 \\
\hline " $\mathrm{T}-3$ & 150 & 80 & 59 & 2.58 \\
\hline ") $\mathrm{T}-4$ & 160 & 60 & 62 & 0.16 \\
\hline
\end{tabular}

第 2 表 水素暨力几依る還元狀態の影警 試料 $50 \mathrm{~g}$; ニッケ儿珪落土 $3 \mathrm{~g}$; 㴚度 $60 \%$ 溶液； 反應溫度 $155^{\circ} \mathrm{C}$

\begin{tabular}{|c|c|c|c|c|c|c|c|}
\hline $\begin{array}{l}\text { 望 驗 } \\
\text { 記 號 }\end{array}$ & $\begin{array}{l}\text { 水素 } \\
\text { 初宦 } \\
\text { (atm) }\end{array}$ & $\begin{array}{l}155^{\circ} \mathrm{C} \text {. } \\
\text { 於计最 } \\
\text { 高盟 } \\
(\mathrm{atm})\end{array}$ & $\begin{array}{l}\text { 終胝 } \\
\text { (atm) }\end{array}$ & $\begin{array}{l}\text { 水素 } \\
\text { 吸收 } \\
\text { 量 } \\
\text { (atm) }\end{array}$ & $\begin{array}{l}\text { 反噟 } \\
\text { 洔間 } \\
\text { (分) }\end{array}$ & $\begin{array}{l}\text { 殘留 } \\
\text { 糖分 } \\
(\%)\end{array}$ & $\begin{array}{l}\text { 生成物 } \\
\text { の狀態 }\end{array}$ \\
\hline No. $\mathrm{P}-1$ & 20 & 33 & 2.6 & 17.4 & 320 & - & $\begin{array}{l}\text { 黑色カラメ } \\
\text { 几牀悬 }\end{array}$ \\
\hline " $\mathrm{P}-2$ & 30 & 43 & 11.6 & 19.0 & 150 & - & $\begin{array}{l}\text { 黑褐色, 水 } \\
\text { 素吸收過量 }\end{array}$ \\
\hline " $\mathrm{P}-3$ & 51 & 78 & 38.0 & 13.0 & 80 & 0.87 & 微褐色 \\
\hline " $\mathrm{P}-4$ & 80 & 120 & 65.0 & 15.0 & 65 & 0.21 & 無 色 \\
\hline
\end{tabular}

第 3 表 觸媒量の反應速度に及ほす影響 試料 $200 \mathrm{~g}$; 水素初厢 $150 \mathrm{~atm}$; 涨度 $71.0 \%$; 反塬溫度 $155^{\circ} \mathrm{C}$

\begin{tabular}{|c|c|c|c|c|c|}
\hline 翼醶記號 & $\begin{array}{c}\mathrm{Ni} \text { 觸媒 } \\
(\mathrm{g})\end{array}$ & $\begin{array}{c}\text { 試料K } \\
\text { 對士る } \\
\text { Ni(\%) }\end{array}$ & $\begin{array}{l}\text { 反雄 } \\
\text { 暗䦓 } \\
\text { (分) }\end{array}$ & $\begin{array}{l}\text { 水 素 } \\
\text { 吸收量 } \\
(\mathbf{a t m})\end{array}$ & $\begin{array}{l}\text { 殘留 } \\
\text { 䒹分 } \\
(\%)\end{array}$ \\
\hline No. $\mathrm{K}-1$ & 1.5 & 0.17 & 150 & 42 & 41.35 \\
\hline " $\quad \mathrm{K}-2$ & 3 & 0.34 & 95 & 72 & 2.48 \\
\hline $\mathrm{K}-3$ & 5 & 0.57 & 70 & 82 & 0.21 \\
\hline $\mathrm{K}-4$ & 10 & 1.15 & 70 & 79 & 0.18 \\
\hline " $\mathrm{k}-6$ & 20 & 2.30 & 75 & 80 & 0.22 \\
\hline
\end{tabular}




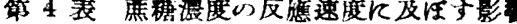
水素初聂 $150 \mathrm{~atm} ; \mathrm{Ni}$ 解媒 $20 \mathrm{~g}$

\begin{tabular}{|c|c|c|c|c|c|c|}
\hline 惯騟記號 & $\begin{array}{c}\text { 斌料 } \\
(\mathrm{g})\end{array}$ & $\begin{array}{l}\text { 水 } \\
\text { (cc) }\end{array}$ & $\begin{array}{l}\text { 浱度 } \\
(\%)\end{array}$ & $\begin{array}{l}\text { 反應 } \\
\text { 時間 } \\
\text { (分) }\end{array}$ & $\begin{array}{l}\text { 水 素 } \\
\text { 吸收量 } \\
\text { (atm) }\end{array}$ & $\begin{array}{l}\text { 残留 } \\
\text { 榶分 } \\
(\%)\end{array}$ \\
\hline No. $\mathbf{C}-1$ & 70 & 160 & 30.4 & 100 & 26 & 0.30 \\
\hline " C-2 & 100 & 140 & 41.0 & 90 & 38 & 0.24 \\
\hline C-3 & 125 & 125 & 50.0 & 80 & 50 & 0.23 \\
\hline$C-4$ & 158 & 105 & 60.0 & 70 & 62 & 0.12 \\
\hline - $\mathrm{C}-5$ & 200 & 80 & 71.4 & 90 & 76 & 0.31 \\
\hline
\end{tabular}

\section{III. 實驗結果の考察}

第 1 表により明かなる如く $150 〜 160^{\circ} \mathrm{C}$ が最適であり，それ以 上の溫度にては脫水分解の倾向がある。此溫度は葡萄啸の場合が $130^{\circ} \mathrm{C}$ 附近より水素吸收反應を起し $140 \sim 150^{\circ} \mathrm{C}$ が適當なる條件 下比し僅か高潈である。晌キシリ、トは $110^{\circ} \mathrm{C}$ 附近で合成されて るる。次に媅力條件は第 2 表に示した如く 30 氣憠以下のものて す水素吸收はあるが反應速度も退く生成物が著しく着色し（但し 後述のアルカリ性溶夜の場合を除き）低厥處理は一應不適當であ る。㯕くとも 60 氣㩐以上は必要に思はれる。

第3 表の觸媒量に關しては凡そ $70 \%$ 濃度試料に對し二,ヶル として $0.5 \%$ 附近より適當であるが，これもォートクレーヴの構 造により (主として買拌條件) 多少條件を異にするし觸媒の再使 用に關しては侗若干問題が殘るものと考へられる。

第 4 表の示寸濃度に關しては他の條件の充分なる範圍に於て比 較的高濃度の場合が反娩時間及び生成物の狀態も良好であるが， 葡萄糖の場合は溶解度の點より操作上に困難な場合を來たす。凡 そ 50 - 70\% の範潿が適當と考へられる。

\section{IV. 水素イオン濃度に關する影響}

上記實驗とは别途にアルカリ性溶液にて行つた結果は極めて顯 著なる影響を示し，大規模の工業化を行ふ場合比較的低溫低原條 件にて行ひ得るものと磪信せられる結果が發見された。要するに 糖類は酸性又は中性溶液ではララトール環型で存在するが，アル カリ性溶液では化學的變化或は轉化を起し易いカーボニル型とし て存在するからであららと考へられ、ニ,ケ几觸媒が有效に活用 せられるに他ならない。
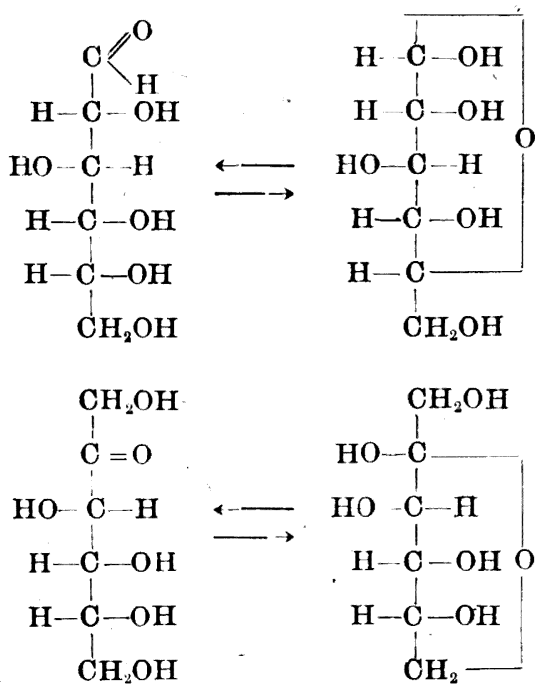

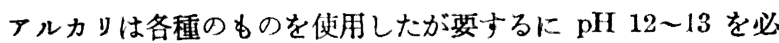

要とし，その點䁈際問題としては苛性ソーダの如き强アルカリが 適當である。斯かる條件に於ては反應㻺 30 氣厢に於ても生成物 は良好であり決して中性溶液に於て示すが如き着色を生ずる事が ない。更に有效な影響として反應溫度が 70 ～ $80^{\circ} \mathrm{C}$ で充分である ことが高溫に對して比較的不安定な炭水化物に對し極めて好影暗 を與へることがその理由であある。

\section{第 5 表 フルカリ水溶液中の糖類の還元K} 於ける反應溫度の低下

\begin{tabular}{|c|c|c|c|c|c|c|c|}
\hline 試料 & $\begin{array}{l}\text { 含量 } \\
\text { (g) }\end{array}$ & $\begin{array}{c}\text { 潦解水 } \\
(\mathbf{c} \cdot)\end{array}$ & $\begin{array}{l}\text { 水素 } \\
\text { 初筐 } \\
\text { (atm) }\end{array}$ & 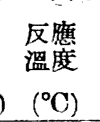 & $\begin{array}{l}\text { 反鹰 } \\
\text { 時間 } \\
\text { (分) }\end{array}$ & $\begin{array}{l}\text { 水素 } \\
\text { 吸收量 } \\
(\mathrm{a}+\mathrm{m})\end{array}$ & 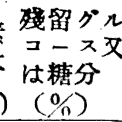 \\
\hline 盏薇糖 & 80 & $150 \mathrm{H}_{2} \mathrm{O}$ & 149 & 145 & 65 & 25 & 0.29 \\
\hline " & 80 & $150 \frac{N}{10} \mathrm{NaOH}$ & 150 & 83 & 50 & 24 & 0.04 \\
\hline 果 榶 & 80 & $150 \mathrm{H}_{2} \mathrm{O}$ & 150 & 142 & 50 & 31 & - \\
\hline " & 80 & $150 \frac{N}{10} \mathrm{NaOH}$ & 150 & 83 & 65 & 31 & $\ldots$ \\
\hline 莣 糖 & 70 & $160 \mathrm{H}_{2} \mathrm{O}$ & 148 & 155 & 80 & 26 & 0.31 \\
\hline " & 80 & $150 \frac{N}{10} \mathrm{NaOH}$ & 150 & $80 \sim 160$ & 90 & 15 & 65.85 \\
\hline
\end{tabular}

上表にて明かなる如く最適溫度を $60^{\circ} \mathrm{C}$ 以上も低下せしめ得る が, 菣糖の場合は直接的には好影響は出ないが, 合他の二糖類, 多糖類に關する研究は續行中である。而して更に興味ある事は初 塺 30 氣塺以下に於ても順調な反應を行ふのであるが反應時間は 勿論長時間を要寸る樣である。

次圖の曲線にその狀態の一例を示す。

試料 蔽萄糖 $80 \mathrm{~g}, \frac{N}{50} \mathrm{NaOH} 150 \mathrm{cc}$ (濃度 $34.7 \%$ ), $\mathrm{Ni}$ 触媒 $5 \mathrm{~g}$

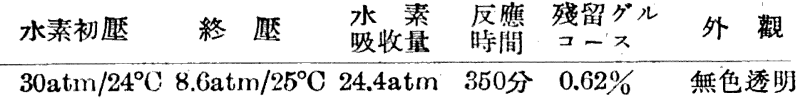
アルカリ性水溶液に於ける邆元圆

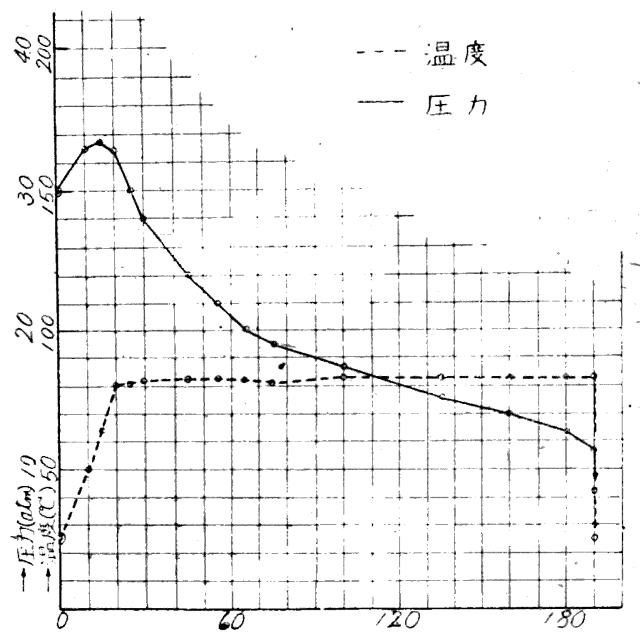

$\rightarrow$ 反應時間 (分)

第 6 表 フルカリ試率门種類と其影繁

試料 蔽萄糖 $80 \mathrm{~g}$, 各アルカリ性溶液 $150 \mathrm{c} \mathrm{c}$

\begin{tabular}{|c|c|c|c|c|c|c|}
\hline $\begin{array}{l}\text { アルカ } \\
\text { リ試料 }\end{array}$ & $\begin{array}{c}\text { 右漫度 } \\
(\mathrm{mol})\end{array}$ & $\begin{array}{l}\text { 水素 } \\
\text { 初暦 } \\
\text { (atm) }\end{array}$ & $\begin{array}{l}\text { 反雄 } \\
\text { 溫度 } \\
\left({ }^{\circ} \mathrm{C}\right)\end{array}$ & $\begin{array}{l}\text { 反應 } \\
\text { 時間 } \\
\text { (分) }\end{array}$ & $\begin{array}{l}\text { 水 素 } \\
\text { 吸收量 } \\
\text { (atm) }\end{array}$ & $\begin{array}{l}\text { 殘留 } \\
\text { 糖分 } \\
(\%)\end{array}$ \\
\hline $\mathrm{NaOH}$ & 0.1 & 150 & 83 & 50 & 24 & 0.04 \\
\hline $\mathrm{Ba}\left(\mathrm{OH}_{2}\right)$ & 0.1 & 101 & 80 & 40 & 26 & 0.18 \\
\hline " & 0.02 & 102 & 85 & 80 & 23 & 0.35 \\
\hline " & 0.01 & 102 & 80 & 80 & 22 & 3.99 \\
\hline $\mathrm{Ca}(\mathrm{OH})_{2}$ & 0.013 & 101 & 84 & 60 & 26 & 1.76 \\
\hline $\mathrm{NH}+\mathrm{OH}$ & 0.05 & 101 & 105 & 150 & 25 & 2.60 \\
\hline
\end{tabular}


上記賽驗結果よりして水素イオン濃度の影響を確認すると同時 に工業的には苦性ソーダの如き强アルカリが適當である。アンモ 二厂の如きも後處理に於てアルカリを除去するに適當らしく考へ られるが $\mathrm{pH}$ 範睹の點より操作に多少無理である。

第 7 表 各アルカリ溶液の $\mathrm{pH}$ K依る影晴

\begin{tabular}{|c|c|c|c|c|c|c|}
\hline $\begin{array}{l}\text { アルカリ試 } \\
\text { 藥の種類 }\end{array}$ & $\begin{array}{l}\text { 水溶液 } \\
\text { の } \mathrm{pH}\end{array}$ & $\begin{array}{r}\text { 水素 } \\
\text { 初蔴 } \\
\text { (atm) }\end{array}$ & $\begin{array}{l}\text { 反應 } \\
\text { 溫度 } \\
\left({ }^{\circ} \mathrm{C}\right)\end{array}$ & $\begin{array}{l}\text { 反噟 } \\
\text { 時間 } \\
\text { (分) }\end{array}$ & $\begin{array}{l}\text { 水素 } \\
\text { 吸收量 } \\
(\mathrm{atm})\end{array}$ & $\begin{array}{l}\text { 殘糖 } \\
\text { 凅分 } \\
(\%) \\
\end{array}$ \\
\hline $\mathrm{NaOH}$ & 13.00 & 150 & 83 & 40 & 24 & 0.04 \\
\hline " & 12.60 & 150 & 80 & 50 & 23 & 2.07 \\
\hline " & 12.30 & 150 & 81 & 60 & 26 & 0.07 \\
\hline " & 12.12 & 141 & 80 & 80 & 25 & $1.85^{\circ}$ \\
\hline " & 12.00 & 150 & 81 & 80 & 23 & 7.19 \\
\hline ' & 11.30 & 150 & 83 & 95 & 11 & 63.85 \\
\hline $\mathrm{NH}_{6} \mathrm{OH}$ & 11.62 & 102 & 90 & 120 & 27 & 1.39 \\
\hline 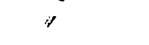 & 11.47 & 101 & 98 & 150 & 28 & 2.59 \\
\hline " & 11.13 & 101 & 105 & 110 & 25 & 20.09 \\
\hline , & 10.97 & 104 & 105 & 130 & 25 & 50.21 \\
\hline $\mathrm{Ca}(\mathrm{OH})_{2}$ & 11.62 & 101 & 85 & 70 & 26 & 1.89 \\
\hline
\end{tabular}

郎ち $\mathrm{pH}$ の範图は溫度 $80^{\circ} \mathrm{C}$ 附近では凡そ $12 \sim 13$ 邊りが適 當の樣に考へられる。アンモニアの場合は $80^{\circ} \mathrm{C}$ 附近では反應速

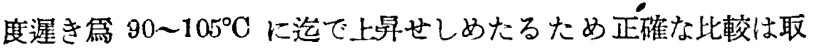
れなかつた。文水酸化カルシウムに於ては溶解度の點よる稍々飽 和の嫌があり, 結局强アルカリの添加が實際問題として許容され る結果を示してるる。然しアルカリは炭水化物類には極めて銳敏 な各種の影響を與へる故に $\mathrm{pH}$ の範葍も比較的嚴密に考へねば
勿論不可である。

逆にか」るアルカリの强影響下に反應を更に進める事により稳 想外の興味ある生成物を得る可能性も考へられる。水素イォン濃 度と溫度との關係により高歷反應の占むる領域は相當撗大せられ るものと信ずる。

\section{V. 綰論}

以上之を要与るに南方資源的に極めて將來性を有する澱粉工業 或は庹く炭水化物工業が糖アルコールの工業的に大量製造し得る 事により有機化學工業の一潩として飛躍的な發展を招來すること は明暸であつて，之が基礎的條件として各種條件を賽驗した。郎 ち高壓還元による場合二,ケルを觸媒として溫度 $130 \sim 150^{\circ} \mathrm{C}$, 瓷 力 60 氣涯以上, 水溶液濃度 50 60\% が好條件であり, 單糖類 に於ては溫度は更に比較的低溫にて可能であるが，菏性ソーがの 如き强アテカリにより稀薄アルカリ性水溶液により著しく高僽條 件を簡易にすることが判つた。

份澱粉その他の多糖類より類推的に直接處理することも無論可 能であり，且高避還元條件の變化により，グリセリン,ブロビレ ングリコール，イソプロピルアルコール等の生成物を得ることも 周知の如く, 又各種の誘導體に合成することにより無數の重要な る化合物を生成せしむるに於ては本工業の䨗將來性あることが信 ぜられる。

附記 : 本研究にあたり恩師小竹無二唯博士の御激嘲を感謝し, 份

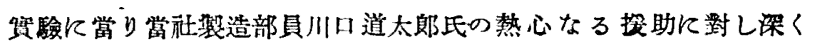
敬意と感謝の意を表する。

\title{
(281) シクロへキサノンのエ業的製造に就て
}

\author{
上野誠一・行森孝男・林幸已
}

\section{緒言}

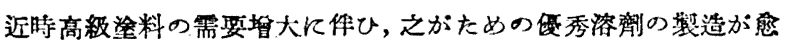
々重䖊せられるに至つた。シクロへキ甘ノンはコロヂオン綿, セル

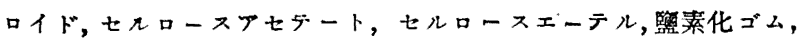
各種樹脂, 油脂, コム等飞對して卓越せる溶解力を有するのみなら ず, 特に塗料溶劑として考境せらるへき種々の條件（蒸發速度，炭 化水素類々對する稀釋察, 其他各種溶劑々の混合割合, 引火點, 燃

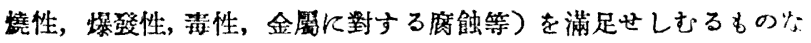

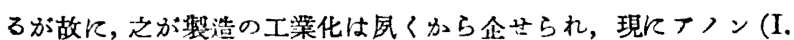
G.), ェクストン (Howerds 及び Sons Co., Ltd.), ヘキ甘ノン (川口化學工業) 等の名稱にて販珼せられて居るが, 本邦內に於け ろ工業的製造は数年前のことにして, 著者等が本研究を開始せる㗬 時（昭和 8 年, 但し一旦中止す）に於ては國內生座は未だ殆ど皆 無の狀態にして大部分之を鐱入に俟つて居た。

著者等は本品がドープ症料の溶劑として, 特に航空機方面に重要 なることよりして,之が國內の工業的製造の急務なる點走認め, 昭

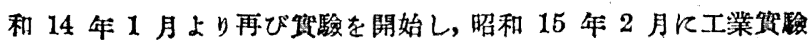

を完了したるる，種くの事情により成縝發表の機會を得なかつを。 然し最近漸く其時機に到りたるを以て，てれを報告することよす 3. シクロへキノンは無色，特異のナトン樣具军を有する浓體にし て、シクロへキサノールをクロム酸にて酸化するか, 又はピメリン

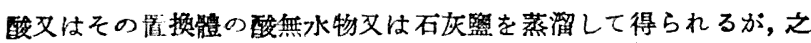
等の方法は䫅雑なる操作技術を要するのみならず，原料に比して製 品の收率惡く，工業的製造として探用することは不得策である。然 るにシクローキサノールを氣相に於て適當なる触媒の存在下に脫 水素反應を行はしむればシクロへキサノンが得られる (Sabatier 隹び Mailhe,Compt. rend., 1905, 140, 350)。然し此方法は操作 極めて简單なるも，触媒の活性が急激に低下すること，及び副作用 として往々脫水作用を併發する等の缺點を有する。之が改良法と して田村周夫, 濑沼交作兩氏（本誌，昭和 9, 37,491）は該解媒 中に數\%の炭酸ナトリウムを混合することを推獎せられ，又井上春 成，田村周夫兩氏は之に更に少量の酸化劑例一ば $\mathrm{Ce}, \mathrm{V}, \mathrm{Cd}, \mathrm{Zn}$, $\mathrm{Mn}$ 等又は其酸化物を加へることに關して特許を得られた（日本 特許 104211 , 昭和 8 年 12 月 18 日特許)。 